\title{
Parotid saliva and rumen digestion in the sheep
}

\author{
By A. D. WILSON* \\ School of Agriculture, University of Melbourne, Australia \\ (Received 29 April 1963-Accepted 29 August 1963)
}

The importance of saliva for the function of the rumen is well recognized. This recognition has arisen from consideration of the volume and composition of ruminant saliva and the needs of the rumen microbial population. Recent estimates indicate that the total salivary secretions of sheep and cattle are of the order of ro and $150 \mathrm{l}$./day respectively (Kay, 1960; Bailey, 1961). These volumes represent more than twice the volume of fluid usually present in the rumen at one time. The inorganic constituents of saliva, principally sodium bicarbonate and phosphate, act as a buffer within the range $\mathrm{pH}_{5 \cdot 5-7}$ (Turner \& Hodgetts, 1955). Microbial digestion is thus favoured by the fluid conditions and the stable $\mathrm{pH}$ of the rumen contents.

McManus (1962) reported that when saliva was collected from sheep the concentrations of volatile fatty acids (VFA) in the rumen were abnormally high. However, in his work there were no control experiments to measure other effects, such as lateral recumbency, upon the concentration of VFA in the rumen, and no experiments to show that the quantity of VFA, as distinct from concentration, had been altered.

This paper describes a number of experiments in which several features of rumen digestion were recorded in sheep, before and after section of the parotid nerves and ducts. The parotid glands were chosen for this work because they normally secrete from 40 to $50 \%$ of the total saliva (Kay, 1960).

\section{EXPERIMENTAL}

A summary of the experiments is given in Table $\mathrm{I}$. The sheep used were all Corriedale wethers, and in Expts 1,3 and 6 each sheep was fitted with a rumen fistula.

The lucerne given in Expt 3 was similar to that given in Expts 1, 2 and 7, except that it was passed through a hammer mill. The straw given in Expts 5 and 6 differed only in the degree to which it was milled.

\section{Operation to section parotid nerve and duct}

Each sheep was anaesthetized with pentobarbital sodium. An incision was made on the cheek above the masseter muscle, and the parotid duct, together with its associated nerve, was tied with silk and sectioned. After the operation, a swelling developed around the gland, but it subsided within $24 \mathrm{~h}$. In Expts I A and 7, the operation was performed on only one gland at a time, but in the other experiments it was performed on both glands at the same time.

- Present address: Regional Pastoral Laboratory, CSIRO, Deniliquin, NSW, Australia. 


\section{Ad lib. feeding}

Expts 1-6. In each experiment there was a preliminary feeding period of at least 2 weeks. It was followed by a period of 2-3 weeks, during which the amount of dry matter eaten was recorded. Once daily each sheep was offered an amount of food that allowed about $15 \%$ to be left uneaten. Samples of the foods and residues were dried at $100^{\circ}$ for $24 \mathrm{~h}$, to determine their dry-matter contents. The measurement of food intake was repeated after each operation.

Table I. Summary of the experiments

\begin{tabular}{|c|c|c|c|c|}
\hline $\begin{array}{l}\text { Expt } \\
\text { no. }\end{array}$ & $\begin{array}{c}\text { Sheep } \\
\text { no. }\end{array}$ & Diet & $\begin{array}{l}\text { Number of parotid } \\
\text { ducts and the } \\
\text { associated nerves } \\
\text { sectioned }\end{array}$ & Variables measured \\
\hline I A & 1,2 & Lucerne chaff & One, then both & $\begin{array}{l}\text { Food intake, rate of passage, } \\
\text { rate of cellulose digestion, } \\
\text { digestibility of dry matter, } \\
\text { water intake }\end{array}$ \\
\hline I $\mathrm{B}$ & $x, 2$ & $\begin{array}{l}\text { Lucerne chaff; drinking } \\
\text { water replaced by } \\
\text { artificial saliva }\end{array}$ & Both & $\begin{array}{l}\text { Food intake, digestibility of } \\
\text { dry matter, water intake }\end{array}$ \\
\hline 2 & 3,4 & Lucerne chaff & Both & Food intake \\
\hline 3 & 5,6 & Lucerne hay* & Both & $\begin{array}{l}\text { As for Expt I A; also dry- } \\
\text { matter content and } \mathrm{pH} \text { of the } \\
\text { rumen contents }\end{array}$ \\
\hline 4 & 7,8 & Hay $†$ & Both & Fond intake \\
\hline 5 & 9,10 & Straw $†$ & Both & Food intake \\
\hline 6 & 11,12 & Straw* & Both & As for Expt 3 \\
\hline 7 & 1,2 & $\begin{array}{l}\text { Lucerne chaff (intake } \\
\text { restricted) }\end{array}$ & One, then both & $\begin{array}{l}\text { Rumen } \mathrm{pH} \text {, concentrations } \\
\text { of rumen VFA and am- } \\
\text { monia N, salivary secretion }\end{array}$ \\
\hline
\end{tabular}

Expts I, 3 and 6. In these experiments, recordings of the rate of passage of food through the digestive tract, the rate of cellulose digestion, the digestibility of the dry matter, and water consumption were made in addition to recording the food intake. The sheep were fitted with harness and bags for faecal collections.

The rate of passage of food was determined by the method of Balch (1950) with the modifications described by Coombe $\&$ Tribe ( 1963$)$, and was expressed as the mean retention time. The rate of cellulose digestion was determined by the cotton-thread technique of Hoflund, Quin \& Clark (1948) with the modifications described by Coombe \& Tribe (1963). The results were expressed as the time required to digest $50 \%$ of the thread. The total faeces were weighed and sampled for 10-14 days, and the dry matter excreted was determined. From this value and the food intake, the digestibility of dry matter was calculated.

Expts 3 and 6. In these experiments additional recordings of the dry matter and $\mathrm{pH}$ of the rumen contents were made. Balch (1950) noted that the rumen contents of 
cows given ground hay were of even consistency throughout and apparently not divided into well-defined dry and liquid layers. The diets used in Expts 3 and 6 had been ground, and therefore it is probable that the samples taken from the rumen were representative of the whole of the contents.

For 5 consecutive days, a sample of rumen contents was taken from each sheep at 9 am (immediately before feeding) and at $\mathrm{I}$ pm. Each sample (approximately $65 \mathrm{ml}$ ) was taken in a standard manner through the rumen fistula with a 0.5 in. diameter glass tube. The $\mathrm{pH}$ of these samples was taken immediately with a Phillips PR $9400 \mathrm{pH}$ meter, and the samples were then dried at $100^{\circ}$ for $24 \mathrm{~h}$.

Expt $\mathrm{r} B$. After the completion of Expt $\mathrm{A} A$, the sheep in that experiment (with both parotid ducts sectioned) were used in Expt 1 B. This experiment consisted of a 12-day feeding period in which food intake, digestibility of dry matter and water consumption were measured as before, except that the drinking water was replaced by artificial saliva. The composition of this saliva was similar to that suggested by McDougall (1948) and is shown in Table 2.

Table 2. Expt $\mathrm{I} B$. Composition of the artificial saliva given to the sheep

\begin{tabular}{lc}
\multicolumn{1}{c}{ Ingredient } & $\begin{array}{c}\text { Concentration } \\
(\mathrm{g} / 1 .)\end{array}$ \\
$\mathrm{NaHCO}_{3}$ & $10 \cdot 0$ \\
$\mathrm{Na}_{2} \mathrm{HPO}_{4} \cdot 2 \mathrm{H}_{2} \mathrm{O}$ & 5.0 \\
$\mathrm{NaCl}$ & 0.5 \\
$\mathrm{KCl}$ & 0.6 \\
Urea & 0.4
\end{tabular}

\section{Expt 7. Restricted feeding}

Between the feeding periods described above for sheep nos. I and 2 in Expt $\mathrm{A}$, the food intake was restricted for 3 weeks and the $\mathrm{pH}$ of the rumen contents, the concentration of total VFA and of ammonia nitrogen in the rumen were determined, together with the rate of salivary secretion. To remove the effect of a varying food intake on the results, these recordings were made when the sheep were given a constant amount of food.

Sheep no. I was offered $800 \mathrm{~g}$, and sheep no. $2700 \mathrm{~g}$, of the diet in a single daily feed. During one $24 \mathrm{~h}$ period in the $2 \mathrm{nd}$ week of restricted feeding, rumen samples were collected at intervals of $2 \mathrm{~h}$ from 9 am (food offered) to $9 \mathrm{pm}$, and every $4 \mathrm{~h}$ for the remaining $\mathrm{I} 2 \mathrm{~h}$. The $\mathrm{pH}$ of each sample was recorded immediately after collection. The concentration of VFA in these samples was determined by the method described by Coombe \& Tribe ( 1963 ), and the concentration of ammonia $\mathrm{N}$ by the method of Seligson \& Seligson (195I) after dilution of the rumen contents as described by Coombe \& Tribe (1963).

During the 3 rd week of restricted feeding measurements of the salivary secretion were made as follows. Each sheep was anaesthetized with pentobarbital sodium and both the parotid ducts were temporarily cannulated through the papillas. The salivary glands were reflexly stimulated by inflating a 6 in. long balloon of low elasticity to a pressure of $25-30 \mathrm{~mm}$ mercury in the lower thoracic oesophagus. The saliva flowing 
from each parotid gland was collected for $12 \mathrm{~min}$ and weighed, and the residual saliva flowing from the mouth was collected for the last $6 \mathrm{~min}$ of this period. The depth of anaesthesia varied between that which allowed strong flexor reflexes of the limbs and that in which they were abolished. The left parotid duct was then located through an incision from outside the cheek, and cannulated just posterior to the papilla. The cannula was of shaped polyethylene tubing ( $1.5 \mathrm{~mm}$ bore, $2.0 \mathrm{~mm}$ diameter) and ran from the cheek under the wool to a point approximately 2 in. in front of the brisket. From the cannula, the saliva dripped into a measuring cylinder. No saliva was lost into the feed bin and evaporative losses were small. For 3.5 days, the saliva was collected at $9.00 \mathrm{am}, 3.00 \mathrm{pm}$ and $9.00 \mathrm{pm}$, the volume recorded and the saliva then returned to the sheep through the rumen fistula. Sodium bicarbonate containing I $50 \mathrm{~m}$-equiv. sodium was added to the returned saliva daily to ensure that the sheep were in positive sodium balance.

The cannula was then withdrawn, the left parotid nerve and duct were sectioned and the sheep were returned to Expt I A. In the next feeding period, after the operation on the left parotid gland, the right parotid and residual secretions were recorded as described in the preceding paragraph. In the feeding period after the operation on the right gland, the residual secretions were recorded.

\section{RESULTS}

Food intake

The mean food intakes of the sheep in each experiment are shown in Tables 3 and 4 , and the daily changes in food intake for the sheep in Expts I A, I B, 4 and 5 are shown in Fig. I. In the analysis of the values in Table 4, the interactions of sheep with treatment within diets were combined over the separate diets to give a pooled error with 7 degrees of freedom. There was no evidence of differences in treatment response

Table 3. Expts I $A$ and I $B$. Mean values with their standard errors for daily dry-matter food intakes $(\mathrm{kg})$ of the sheep

State of parotid glands
Intact
One denervated
Two denervated
'Two denervated (Expt I B)

$$
\begin{aligned}
& \text { Food intake } \\
& 1.83 \pm 0.267 \\
& 1.57 \pm 0.116 \\
& 1.05 \pm 0.223 \\
& 1.55 \pm 0.223
\end{aligned}
$$

Table 4. Mean food intakes $(\mathrm{kg})$ of the sheep before and after section of both parotid nerves and ducts

\begin{tabular}{lcccl}
\multicolumn{5}{c}{ Mean intake } \\
Expt & Before & After & Difference & Significance \\
I A+2 & 1.87 & $1 \cdot 10$ & 0.77 & $P<0.001$ \\
3 & 0.79 & 0.91 & -0.12 & $P<0.05$ \\
4 & $1 \cdot 15$ & 0.75 & 0.40 & $P<0.001$ \\
5 & 0.66 & 0.55 & 0.11 & $P<0.05$ \\
6 & 0.69 & 0.71 & -0.02 & NS
\end{tabular}

NS, not significant. 
in Expts $\mathrm{IA}$ and 2, so that the results have been combined. After each operation the intake was depressed for 3-5 days and these values have been excluded from the means presented in Table 3 , since they were probably a result of the surgery per se and not of changes in the salivary secretion. In some experiments, there was a small increase in food intake after the $5^{\text {th }}$ postoperative day, but there was no indication that the intake would have increased to the levels recorded before the operation. In Expts I A and 2 there was a mean decrease of $42 \%$, in Expt 4 a decrease of $35 \%$ and in Expt 5 a decrease of $17 \%$, in the daily food intake after section of the parotid nerves and ducts. When, in Expt I B, the drinking water was replaced by artificial saliva, the mean food intake returned to a level only $15 \%$ below the original intake.

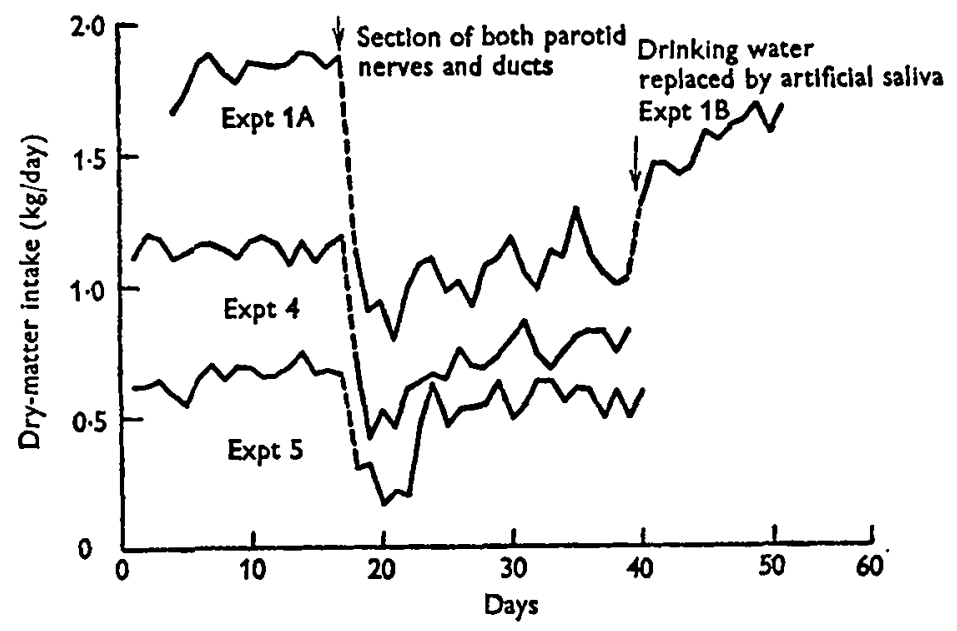

Fig. I. Mean daily food intake of the sheep in Expts $1 \mathrm{~A}$, I $B, 4$ and 5 . In Expt I A, the values for intakes after section of only one parotid nerve and duct have been omitted. The broken lines join the recordings made on the day before and the day after the operation, or the introduction of artificial saliva.

Table 5. Mean values for the retention time, rate of cellulose digestion, dry-matter digestibility and the dry-matter content and $p H$ of the rumen contents in sheep before and after section of both parotid nerves and ducts

\begin{tabular}{|c|c|c|c|c|c|c|c|c|c|c|c|c|}
\hline \multirow[b]{2}{*}{ Expt no. } & \multicolumn{2}{|c|}{$\begin{array}{l}\text { Mean } \\
\text { retention } \\
\text { time (h) }\end{array}$} & \multicolumn{2}{|c|}{$\begin{array}{c}\text { Rate of } \\
\text { cellulose } \\
\text { digestion }(h)\end{array}$} & \multicolumn{2}{|c|}{$\begin{array}{c}\text { Dry-matter } \\
\text { digestibility } \\
(\%)\end{array}$} & \multicolumn{2}{|c|}{$\begin{array}{l}\text { Water intake } \\
\text { (l. } / \mathrm{kg} \text { food } \\
\text { intake) }\end{array}$} & \multicolumn{2}{|c|}{$\begin{array}{l}\text { Dry matter } \\
\text { of rumen } \\
\text { contents }(\%)\end{array}$} & \multicolumn{2}{|c|}{$\begin{array}{l}\mathrm{pH} \text { of } \\
\text { rumen } \\
\text { contents }\end{array}$} \\
\hline & Before & After & Before & After & Before & After & Before & After & Before & $\overrightarrow{\text { After }}$ & Before & After \\
\hline I A & 35 & 63 & $2 I$ & 29 & 58 & 62 & 2.9 & 2.8 & - & - & - & - \\
\hline 3 & 43 & 52 & 20 & 33 & 54 & 55 & 2.5 & 2.4 & $9 \cdot 7$ & 13.5 & $6 \cdot 9$ & 6.7 \\
\hline 6 & 54 & 65 & 23 & 32 & $3^{8}$ & 45 & $3 \cdot 3$ & $3 \cdot 0$ & $8 \cdot 3$ & & $7 \cdot 0$ & 00 \\
\hline
\end{tabular}




\section{Rate of cellulose digestion, rate of passage of food and dry-matter digestibility}

After section of both parotid nerves and ducts there was a decrease in the rate of passage of food and in the rate of cellulose digestion (Table 5). There was a slight increase in the digestibility of dry matter and no real change in the water intake relative to the food intake (Table 5). In Expt I $B$ the mean intake of artificial saliva was $5.31 . / \mathrm{kg}$ food intake and the mean digestibility of dry matter was $59 \%$. The proportion of dry matter in the rumen contents increased and the $\mathrm{pH}$ of the rumen contents decreased after section of the parotid ducts and nerves (Table 5).
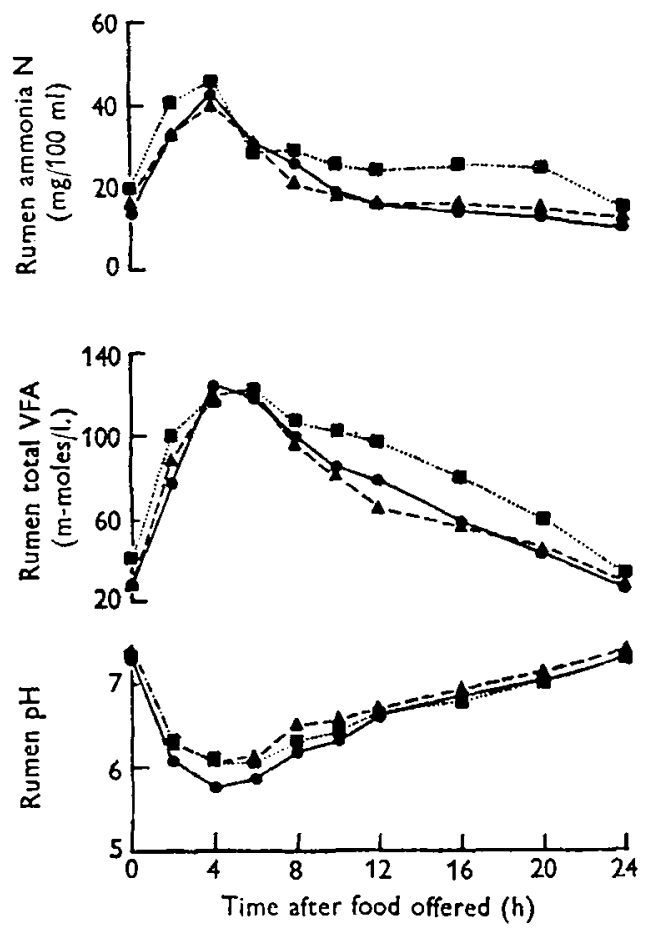

Fig. 2. Concentrations of rumen ammonia nitrogen and total volatile fatty acids, and the rumen $\mathrm{pH}$ in sheep no. 2 when the food intake was restricted to $700 \mathrm{~g}$ lucerne chaff daily with two $(-\bullet)$, one $(\Lambda \ldots \Delta)$ and no $(\boldsymbol{\square} \cdots)$ ) secreting parotid glands.

\section{Concentration of VFA and ammonia $N$ and the $p H$ of the rumen contents}

The changes in the rumen $\mathrm{pH}$ and the concentrations of rumen VFA and ammonia $\mathrm{N}$ are shown in Fig. 2. The results for sheep no. $\mathrm{I}$ were similar in all respects to those for sheep no. 2.

\section{Salivary secretions}

The amounts of saliva secreted are shown in Table 6 . The secretion rates from the two parotid glands of sheep no. 1 , when intact and anaesthetized, were the same, but in sheep no. 2 the left gland secreted at a faster rate than the right gland. Five weeks after section of the left parotid duct and nerve, there was an increase in secretion by 
the right gland of $64 \%$ for sheep no. I and $63 \%$ for sheep no. 2. There were also increases in the secretion of residual saliva. In the conscious sheep there were similar changes. In sheep no. I, the right gland secreted $65 \%$ more saliva than the left gland had secreted before section of its nerve and duct. It is assumed that this represents an increase of approximately $65 \%$, since the two glands originally secreted at the same rate under anaesthesia. The magnitude of the change for sheep no. 2 cannot be determined, because the two glands did not originally secrete at the same rate and because the cannula frequently became blocked when recording the secretion of the left gland.

Table 6. Expt 7. Amounts of saliva secreted

\begin{tabular}{|c|c|c|c|c|c|c|}
\hline \multirow[b]{2}{*}{ Sheep no. } & \multirow[b]{2}{*}{$\begin{array}{l}\text { No. of secreting } \\
\text { parotid glands }\end{array}$} & \multicolumn{3}{|c|}{ Anaesthetized sheep ( $\mathrm{g} / \mathrm{min})$} & \multicolumn{2}{|c|}{$\begin{array}{l}\text { Conscious sheep }(1 . / 12 \mathrm{~h}) \\
\text { (mean values and standard } \\
\text { errors for seven recordings) }\end{array}$} \\
\hline & & $\begin{array}{c}\text { Left } \\
\text { parotid }\end{array}$ & $\begin{array}{l}\text { Right } \\
\text { parotid }\end{array}$ & Residual & Left parotid & Right parotid \\
\hline I & $\begin{array}{l}\text { Two } \\
\text { One } \\
\text { None }\end{array}$ & $\begin{array}{l}5 \cdot 4 \\
\mathrm{LS} \\
\mathrm{LS}\end{array}$ & $\begin{array}{l}5 \cdot 4 \\
8 \cdot 9 \\
\text { RS }\end{array}$ & $\begin{array}{l}3 \cdot 7 \\
4.7 \\
6 \cdot 3\end{array}$ & $\begin{array}{l}\text { I.2I } \pm 0.077 \\
\text { LS } \\
\text { LSS }\end{array}$ & $\begin{array}{c}\mathrm{NC} \\
2 \cdot 00 \pm 0.264 \\
\mathrm{RS}\end{array}$ \\
\hline 2 & $\begin{array}{l}\text { Two } \\
\text { One } \\
\text { None }\end{array}$ & $\begin{array}{l}6 \cdot 8 \\
\mathrm{LS} \\
\mathrm{LS}\end{array}$ & $\begin{array}{l}5 \cdot 4 \\
8 \cdot 8 \\
\text { RS }\end{array}$ & $\begin{array}{l}3 \cdot 5 \\
2 \cdot 3 \dagger \\
4 \cdot 3\end{array}$ & $\begin{array}{c}0.62 \pm 0.039^{*} \\
\text { I.S } \\
\text { LSS }\end{array}$ & $\begin{array}{c}\mathrm{NC} \\
\mathrm{I} \cdot 93 \pm 0 \cdot 147 \\
\mathrm{RS}\end{array}$ \\
\hline
\end{tabular}

LS, left parotid duct sectioned; RS, right parotid duct sectioned; NC, not cannulated.

- Cannula frequently blocked.

+ Some saliva swallowed.

\section{DISCUSSION}

\section{Ad lib. feeding}

Regardless of the diet, section of the parotid ducts was followed by a decrease in the rate of passage of food, a decrease in the rate of cellulose digestion, and in all Expts except 3 and 6 a decreased food intake. There was no evidence of an increase in water intake when the salivary secretion was decreased. The increase of $0.5 \mathrm{~kg} /$ day in the food intake of the sheep when provided with artificial saliva showed that the changes in the rate of digestion and food intake after section of both nerves and ducts were due to the decreased salivary secretion and not to any effects of the operation per se. The provision of artificial saliva increased the intake of both salts and fluid, so that it is not possible to decide which factor of saliva was responsible for the increased food intake.

Results obtained by Campling, Freer \& Balch (196I) and Blaxter, Wainman \& Wilson (196r) indicate that voluntary intake of roughages by ruminants is determined by the fill of the reticulo-rumen, which in turn is affected by the rate of passage and digestibility of the food. In the experiments described here, it is probable that the decrease in food intake was the result of the slower rate of digestion in the rumen and of the decreased rate of passage of food from the rumen.

In Expts 3 and 6 the roughages offered had been hammer-milled through a 0.25 in. screen. In Expt 3 the mean initial intake of ground lucerne $(0.79 \mathrm{~kg} /$ day) was below the mean final intakes $(1 \cdot 10 \mathrm{~kg} / \mathrm{day})$ recorded with the unground lucerne diets in Expts I A and 2, so that no further reduction in intakes would be expected. 
The slower rate of cellulose digestion may have been due to the drier rumen contents, since Balch \& Johnson (1950) found that the rate of cellulose digestion was favoured by more fluid conditions in the rumen. The slower rate of passage of food may also have been due to this cause.

The increase in digestibility of dry matter that occurred after the section of the parotid ducts was probably due to the slower rate of passage of food, and in Expt i A to the decreased food intake.

\section{Restricted feeding}

In Expt 7 the concentrations of rumen VFA and ammonia $N$ reached a peak approximately $4 \mathrm{~h}$ after feeding, which was followed by a gradual decline to the lowest levels just before feeding on the next day. The loss of function of one or both parotid glands had little effect on these patterns of either rumen VFA or rumen ammonia N. The rise in concentrations was as rapid as, and the highest recordings were similar to, those in the intact sheep. In the sheep without functional parotid glands, the concentrations were slightly higher from 8 to $24 \mathrm{~h}$ after feeding, suggesting that there was less salivary dilution during that time. However, in this experiment changes in the volume of the rumen contents were not measured, so that the absolute production of VFA and ammonia $\mathrm{N}$ cannot be calculated. The $\mathrm{pH}$ values of the rumen contents also remained unaltered, suggesting that the buffering capacity of the rumen contents had not been impaired.

The recordings of salivary secretion show that the sheep tended to compensate for the loss of functional parotid glands by increasing the secretion of the remaining glands. In Expt 7 the compensation was large, and it was accordingly not surprising that the concentrations of rumen VFA and ammonia $\mathrm{N}$ remained unchanged. However, the recordings of salivary secretion do not necessarily apply to the other experiments because salivary secretion is affected by the quantity and nature of the food eaten (Wilson \& Tribe, 1963).

The compensatory increases in secretion may have been due to several factors. It is possible that the remaining salivary glands increased in weight. Emmelin, Jacobsohn \& Muren (195I) observed that, after section of the chorda tympani to the right submaxillary gland of cats, the left submaxillary gland increased in weight. A similar effect could have occurred with the parotid glands in these experiments, but the effect of denervation on the other glands is not known.

The increased secretion may also have been due to an increased secretion by the remaining glands, without further growth of gland tissue. Normally the volume of parotid saliva secreted is related to the quantity of food eaten (Wilson \& Tribe, r 963) and in Expt 7 the food intake was restricted. Therefore, the glands were capable of a much larger secretion. The remaining functional parotid gland secreted 4 l. saliva/day, which is still within the range of volumes recorded from one parotid gland of normal sheep (Denton, 1957; Kay, 1960; Wilson \& Tribe, 1963). If the increase in secretion had been due to this factor, there would have been less compensation in Expts I A, 2 and 4 than in Expt 7 , because of the higher initial food intake in those experiments. The mechanism for such an increase in secretion could have been a change in the 
ruminating behaviour of the animal, an increased reflex stimulation from the rumen following a change in the nature of the rumen contents, or a decreased inhibition of secretion because of the smaller volume of the rumen contents. Denton (1957) noted that sheep with unilateral parotid fistulas tended to chew more on the unfistulated side of the mouth. In the conscious sheep a similar effect may have contributed to an increase in the secretion of the right gland after the operation on the left gland, but it is doubtful if this would have affected the parotid secretion in the anaesthetized sheep. Changes in the rumination time could also have affected the secretion in the conscious sheep. Wilson \& Tribe ( 1963 ) observed that infusion of saliva into the rumen resulted in a marked decrease in parotid secretion. They attributed this decrease to an increased inhibition of secretion by the greater volume of rumen contents. The reverse could be true in my experiment.

It is apparent from these experiments that parotid saliva is essential for maintaining a high rate of digestion in the reticulo-rumen of sheep, particularly with high-quality diets that are eaten in large amounts. It is not suggested that saliva is less important for the digestion of diets of lower quality, but that saliva is required in proportion to food intake, and at the lower intakes sufficient saliva may be provided by the other salivary glands to maintain the food intake.

\section{SUMMARY}

I. Twelve sheep were given ad lib. either lucerne-chaff, hay or straw diets. Recordings were made of the voluntary food intakes, before and after section of the parotid nerves and ducts. In six sheep, recordings were also made of the rate of passage of food, rate of cellulose digestion, digestibility of dry matter and water intake.

2. Section of the parotid ducts and nerves decreased the intake of the lucerne-chaff diet by $42 \%$ and of the hay diet by $35 \%$, but had less, or no, effect on the intake of diets of straw or milled lucerne hay. Subsequently, when the drinking water of two of the sheep receiving the lucerne-chaff diet was replaced by artificial saliva, the food intake increased to only $15 \%$ below the initial intake. Section of the nerves and ducts decreased the rate of passage of food and the rate of cellulose digestion, slightly increased the digestibility of dry matter and did not affect the water intake.

3. In two sheep receiving a fixed amount of the lucerne-chaff diet, there was little change in the concentrations of rumen volatile fatty acids and ammonia nitrogen or in the rumen $\mathrm{pH}$, after section of the parotid nerves and ducts. After section of the nerve and duct to the left parotid gland, there was an estimated increase of approximately $64 \%$ in the secretion by the right parotid gland. After section of one or both ducts and nerves, there was an increase in the secretion of residual saliva.

For the duration of this work, the author was the holder of an Australian Dairy Produce Board studentship. The author is indebted to Dr D. E. Tribe and Mr N. M. Tulloh, School of Agriculture, University of Melbourne for their interest in this work and for their discussion of the manuscript and to $\mathrm{Mr} \mathrm{G}$. A. McIntyre, Division of 
Mathematical Statistics, CSIRO, for the statistical analysis. Thanks are due to Miss L. J. Peel for technical assistance and to $\mathrm{Mr}$ B. Coulson for the care of the animals. Financial assistance was received from the Australian Wool Research Committee and the Reserve Bank of Australia (Rural Credits Development Fund).

\section{REFERENCES}

Bailey, C. B. (1961). Brit. F. Nutr. r5, 443.

Balch, C. C. (1950). Brit. F. Nutr. 4, 361 .

Balch, C. C. \& Johnson, V. W. (1950). Brit. Y. Nutr. 4, 389.

Blaxter, K. L., Wainman, F. W. \& Wilson, R. S. (1961). Anim. Prod. 3, 5 I.

Campling, R. C., Freer, M. \& Balch, C. C. (196r). Brit. F. Nutr. 15, 53 I.

Coombe, J. B. \& Tribe, D. E. (1963). Aust. F. agric. Res. 14, 70.

Denton, D. A. (1957). Quart. Y. exp. Physiol. 42, 72.

Emmelin, N., Jacobsohn, D. \& Muren, A. (1951). Acta physiol. scand. 24, 128.

Hoflund, S., Quin, J. I. \& Clark, R. (1948). Onderstepoort J. vet. Sci. 23, 395.

Kay, R. N. B. (1960). F. Physiol. 150, 515.

McDougall, E. I. (1 948). Biochem. F. 43, 99.

McManus, W. R. (1062). Aust. F. agric. Res. 13, 907.

Seligson, D. \& Seligson, H. (1951). \%. Lab. clin. Med. 38, 324.

Turner, A. W. \& Hodgetts, V. E. (1955). Aust. Y. agric. Res. 6, 25.

Wilson, A. D. \& Tribe, D. E. $(1963)$. Aust. F. agric. Res. 14, 670. 